\title{
THE (IN)COHERENCE OF THE EU'S MEDITERRANEAN POLICIES: ANALYSING THE EFFECTS ON IMPLEMENTATION SUCCESS
}

Ana BOJINOVIĆ FENKO

Faculty of Social Sciences, Liubljana

Albina OSREČKI

Ministry of Interior, Zagreb

UDK: 327 (4-6EU)

Izvorni znanstveni rad

Primlieno: 4. 10. 2017.

This article examines whether the implementation of the EU's Mediterranean policies has been unsuccessful due to the incoherence of these policies. Termed as incompatibility of goals among the EMP, the ENP and the UFM, incoherence is analysed in various subfields of the EU's external action, namely in the functional external dimensions of internal policies (Justice and Home Affairs/JHA, Energy, Transport, Environment and Education) and external relations (Trade) on one side, and in Foreign Policy on the other. Functional subfields prove to retain more coherence and higher implementation success, with Education being exemplary. Conversely, political subfields (democratization and respect for human rights) expose incoherence and consequently about $50 \%$ failure of implementation. Nevertheless, in JHA (the fight against irregular immigration and terrorism), where the former functional cooperation became highly politically burdened, results show even higher non-implementation, which bears more general relevance for EU external action policy-making.

Keywords: EU's Mediterranean policies, incoherence, non-implementation, EU external action

Albina Osrečki, Petra Svačića 2,

10361 Sesvetski Kraljevec, Croatia.

E-mail: albinaosrecki@gmail.com 
Looking at the European Union (EU) external action, Mediterranean policies have been in its focus longest; the European Economic Community (EEC) has steered its attention to the Mediterranean space, ever since the foundation of external relations (external trade and development cooperation) in the Treaty of Rome. All EEC/EU policies launched before the Euro-Mediterranean Partnership (EMP) addressed trade primarily, but also financial and technical cooperation, promotion of industrialization and modernization of agriculture; in short it was a functional cooperation via individual agreements with states in the southern and south-eastern Mediterranean. The EEC thus did not aim to develop a (regional) political framework to address conflict-resolution, the main problem in the region (Bojinović Fenko, 2009). Only after the Cold War, did the EEC Member States' and institutions' perceptions reach a convergence about the Mediterranean 'region' being a foreign policy priority (Gomez, 1998, p. 140). However, this new collective EEC impetus did not come as a continuation of the previous functional source of engagement but occurred due to an entirely new impact, i.e. migration from the Mediterranean 'reservoir' to the ECC; King (1998, pp. 125-129) even explains this negative perception of the area as 'Europe's Rio Grande'. Nevertheless, the EU remained focused on trade (King, 1998, pp. 125-129) and did not include goals in irregular immigration subfield into its EU-Mediterranean policy framework until 2005. In 1995, within the launched EMP, the EU added two different kinds of novelties: 1) a multilateral interregional framework of cooperation and 2) political cooperation in the form of two baskets, i.e. common norms and values, and cultural-social affairs promoting understanding between different cultures. There were many critics of extending the previous functional focus to a politically oriented cooperation, as the latter was evidently not based only on the norms of the UN Charter (such as sovereignty and non-intervention in internal affairs) but also on the so-called "common EU-Mediterranean norms and values." This second concept encompassed norms primarily owned and practised by the EU (Member States), such as democracy and respect for human rights, and implemented via EU's normative power (Adler, Bicchi, Crawford, \& Del Sarto, 2006; Pace, 2006).

In 2004, the EMP was complemented (not replaced) by the European Neighbourhood Policy (ENP). Initially aimed only at new eastern EU neighbours after the Big Bang enlargement, it eventually included also Southern Mediterranean Partners (SMPs), who wanted equal attention as Eastern Europe after having been second to the 10 membership candidates for several years. The ENP remained similar to the EMP 
DRUŠ. ISTRAŽ. ZAGREB GOD. 28 (2019), BR. 3, STR. 483-502

BOJINOVIĆ FENKO, A., OSREČKI, A.:

THE (IN)COHERENCE.. in policy focus, but enhanced implementation via bilateral rather than EMP-promoted multilateral instruments. Cardwell (2011, p. 236) has however established that this "disjointed, even chaotic EU approach to the region" resulted in some overlapping EU's Mediterranean policy frameworks which mostly served to pursue internal EU policy goals and have thus strengthened "the ability of the EU to use /.../ the EuroMed system of governance to its own advantage". In 2008, the failure of the EMP to accomplish its two main goals - the Euro-Mediterranean area of peace and stability and EuroMed free trade area - once again called for a novel approach to the area. Contrary to the EMP's high-politics profile, the performance of the next EU's Mediterranean policy the Union for the Mediterranean (UFM), has mainly been functional in nature despite some new added subfields (e.g. higher education and research, transport and urban development) (Bicchi, 2012).

A recent critical analysis of EU-Mediterranean policy application from 2003 to 2017 by Cebeci and Schumacher (2017) shows that the EU's discourse on the Southern Mediterranean serves primarily the EU's identity construction of ideal European self against its imperfect Southern Mediterranean others. It results in the so-called technocratic approach and depoliticization of the EU's policy goals. In this context, our aim is to perform a more in-depth verification of the reasons for such an underachievement of EU external action in the Mediterranean. We presume that this weak implementation correlates to incompatibility of numerous subfields' goals of the three EU's Mediterranean policies, which we term policy incoherence.

We pose the following two hypotheses: 1 . Coherence of EU-Mediterranean policies is higher within subfields that pertain to functional cooperation in comparison to political cooperation; 2. Implementation of EU-Mediterranean policies by SMPs is more successful in subfields that reflect higher coherence, i.e. in the functional cooperation subfields. Methodologically, we focus on three EU-Mediterranean policies that the EU has launched since 1995, the EMP, the ENP and the UFM, and on seven subfields within them, clustered into political cooperation (EU foreign policy) and functional cooperation (EU external relations encompassing trade policy, and externalized internal policies such as JHA, Energy Policy, Transport Policy, Environment Policy and Educational Policy). We first identify policy goals of the individual subfields of each of the three EU Mediterranean policies and then compare them longitudinally. We do not offer a comparison of EMP and UfM as their existence does not overlap in time. We operationalize incoherence as the level of policy goals' compatibility and mea- 
DRUŠ. ISTRAŽ. ZAGREB GOD. 28 (2019), BR. 3, STR. $483-502$

BOJINOVIĆ FENKO, A., OSREČKI, A.:

THE (IN)COHERENCE.. sure it in terms of absence of conflict among these policies' objectives; if level of compatibility is low, this points to incoherence. Finally, we analyse the success in the implementation of these policies in the cases of four SMPs, whereby we operationalize this success via content analysis of deviations in the implementation of policy commitments that selected SMPs took on in their Action Plans and a calculation of the ratio of these commitments' full, partial or non-implementation. A detailed outline of this mixed-methods approach, combining content analysis of EU policies' primary documents, own calculations of subfields' implementation and comparative analysis is provided below under the title Empirical analysis.

The article's contribution is in pointing to the correlation between incoherence of the three EU Mediterranean policies and failure in their implementation in seven subfields specified below, clustered into political and functional cooperation. We thus do not refer to the coherence as compatibility of policy goals among different subfields (functional and political) within one EU Mediterranean policy, but rather to compatibility of goals among the three EU Mediterranean policies applied to particular subfields. In so doing, we restrict our observation of implementation only on the part of SMPs, noting that adopted policy aims must be implemented jointly by the EU (Member States) and SMPs.

\section{CONCEPTUAL FRAMEWORK; INCOHERENCE OF THE EU'S EXTERNAL ACTION}

When referring to the EU external action, we use the all-encompassing understanding of the EU's activities in the international community. We define EU external action according to the Treaty on EU as "the Union's action on the international scene" (Art. 21, para. 1). This action however encompasses quite different policies in terms of substance and policy-making mode due to gradual development of the EEC's Community system of foreign policy (External Trade, Development Cooperation and Humanitarian Assistance), including external dimensions of internal policies (like Agricultural policy, Justice and Home Affairs, Environment, Fisheries) and general externalization of the EU Common Market.

The term coherence generally means compatibility, synchronization, harmony; the quality of forming a unified whole. Smith (2008, p. 73) has applied it to external and internal dimensions of EU policy but initially defined it within a wider concept of consistency. External consistency is not problematized in this article as we deal with the Mediterranean region only, not providing a comparison with other EU-to-region policies. The internal dimension of consistency, however, is 
DRUŠ. ISTRAŽ. ZAGREB GOD. 28 (2019), BR. 3, STR. 483-502

BOJINOVIĆ FENKO, A., OSREČKI, A.:

THE (IN)COHERENCE.. further conceptualized into horizontal and vertical consistency. The meaning of vertical consistency is the most commonly used, generally referring to coordination, conformity, concurrence, harmonization; it is about the quality of achieving a level of performance which does not vary greatly in quality over time. As this phenomenon of measuring (the avoidance of) contradictions among different policy actors within the EU policy process (Den Hertog \& Strob, 2013, p. 376) is highly researched, it is also not investigated here.

The focus of this research is thus on the horizontal consistency, further termed by Smith (2008, p. 73) as coherence of EU policies. This phenomenon denotes compatibility and even mutual reinforcement of external measures and actions taken in each pillar or simply as compatibility of some EU policies in terms of absence of conflict among these policies' objectives (Smith, 2008, p. 73). Defining coherence more in depth, the authors refer to compatibility of various types of policies that the EU performs in its external action. For example, Gauttier (2004, p. 23) asserts that in the context of EU external action, coherence signifies the synergy between externalized internal policies of the EU. Tietje (1997, p. 212) defines coherence as the extent to which both levels of EU external action (foreign policy and external relations with all three abovementioned components) are logically interlinked so that they complement each other, whereas Gebhard (2011, p. 114) refers to coherence as a tendency to coordinate EU external relations with EU foreign policy with the aim to strengthen their strategic convergence. All these definitions of coherence converge in the notion of compatibility of individual EU policies (Bretherton \& Vogler, 2006, p. 32), which we regard as the most indubitable definition of coherence and for this reason we apply it in this article. Coherence of EU policy goals has been thoroughly empirically researched through different perspectives (e.g. Duke, 2011, pp. 15-54; Den Hertog \& Strob, 2013, pp. 373-388; Portela \& Raube, 2012, pp. 3-20; Thomas, 2012, pp. 457-474; Carbone, 2008, pp. 323-342).

It is important to refer to the coherence of policy goals and to the consistency of their implementation as two different phenomena of EU's capability for actorness (Bretherton \& Vogler, 2006) which ontologically exists in two different policy-making phases. If coherence refers to the compatibility of goals of different policies, it is thus 'active' in the decision-making phase, but also bears heavily on the success of the implementation of the policy. On the other hand, consistency between actors while carrying out the same policy refers only to the implementation phase of that policy. This is highly relevant for the operationalization of our research. As Krenzler and Schneider (1997, p. 134) explain, the difference between 
DRUŠ. ISTRAŽ. ZAGREB GOD. 28 (2019), BR. 3, STR. 483-502

BOJINOVIĆ FENKO, A., OSREČKI, A.:

THE (IN)COHERENCE.. the (vertical) consistency and coherence (horizontal consistency) is very subtle, but significant when applied to EU external action; consistency is a coordinated activity among EU institutions as structures which conduct joint regular meetings on common policy issues, whereas coherence is linked to the substance of adopted decisions (or policy aims).

What Nuttall (2005, pp. 93-97) points to is not so much terminological difference between the two concepts which he describes as 'linguistic pedantry', but to the interlinkage between them. Consistency determines the ability of the EU to 'speak with one voice' in exercising its external action, while coherence serves as an indicator of the EU's abilities to act as an international actor.

\section{EMPIRICAL ANALYSIS}

To analyse the coherence of the EU's Mediterranean policies we compare their aims by content analysis of their founding documents: the Barcelona Declaration (1995) inaugurating the EMP, ENP Strategy Paper (2004) in its Mediterranean component and the Joint Declaration of the Paris Summit for the Mediterranean (2008) which launched the UFM. The UFM is supposed to 'continue the aims of the EMP,' particularly in the political sphere which calls for 'creating a zone of peace, stability and security in the Mediterranean' (Barcelona Declaration, 1995, $\mathrm{p}$. 8). Likewise, although the ENP Strategy Paper (2004, p. 6) lays emphasis on the 'continuity of EMP', ENP's agenda safeguards political and security interests of EU Member States (energy security, combating irregular immigration and trans-border crime) and not the common Euro-Mediterranean agenda as accentuated in the Barcelona Declaration (1995, p. 2).

As to the implementation of these policies, we analyse the degree of implemented decisions on the part of the SMPs which they jointly adopted with EU Member States at the Euro-Mediterranean conferences (EMCs). Through the analysis of bilateral action plans (APs), we monitor deviations in the implementation of commitments that selected partners took on (Morocco, Egypt, Lebanon and Jordan), thus determining the implementation success on their side. Our analysis is based on the first series of APs adopted in the period of 2005-2007 for two reasons, one of substantive and one of methodological nature. First, in accordance with conclusions from the Seventh Euro-Mediterranean Conference (Luxembourg, 2005a, p. 5), APs should have intensified dialogue in the political field (with particular emphasis on democratization and human rights) and in the JHA field (with emphasis on combating irregular immigration), which we chose as the focus of our analysis. As the fight against terrorism was added to the EMP at this conference, forming a fourth "JHA and irregular 
immigration" basket, we include this subfield as well. Second, not all the selected SMPs have adopted the second series of APs, and some APs are concluded for different intervals, which prevents uniformity of data and comparative analysis.

\section{Incoherence of the EU's Mediterranean Policies}

The focus of our analysis is first on the decision-making phase of EU's Mediterranean policies where policy aims are defined. We analyse potential incompatibility of aims between the EMP, the ENP and the UFM within several subfields, like foreign policy subfields, trade and a number of the EU's externalized internal policies. The results of content analysis are presented in Table 1.

(1) There is a high level of incompatibility of foreign policy-related aims between the EMP and the ENP. The EP laid emphasis on good neighbourly relations and mutual observance of norms on the part of the EU and SMPs. Conversely, the ENP focused on the EU's interests only (energy security and combating irregular immigration from the south), which led to incoherence in foreign policy-related aims between the two EU Mediterranean policies. Since the UFM has continued the foreign policy aims of the EMP, the incoherence of these aims between the ENP and the UFM remains also after 2008.

(2) The JHA aims are not compatible between the EMP and the ENP. The main difference is that combating terrorism and observing the common norms had priority in the EMP, but irregular immigration was accentuated within the ENP. Low-level compatibility of the aims exists between the ENP and the UFM because the latter laid emphasis on combatting terrorism and on common norms with no reference to irregular immigration and trans-border crime.

(3) Trade policy aims are incompatible between the EMP which promoted a common Euro-Mediterranean free trade area and the ENP which introduced simple bilateral free trade agreements (FTAs). The UFM was based on some regional economic projects (e.g. entrepreneurship) but has not developed its trade policy and has thus stepped away even from the idea of an FTA.

(4) The aims of energy policy are incompatible between the EMP which promoted inter-connectivity in energy supplies between the EU and SMPs, and the ENP which safeguarded the EU's energy interests only. Incompatibility of aims exists between the ENP and the UFM as well, since the UFM has laid emphasis on Mediterranean projects of renewable energy resources which have not been in compliance with the traditional ones (oil and gas) that had been promoted by the ENP. 


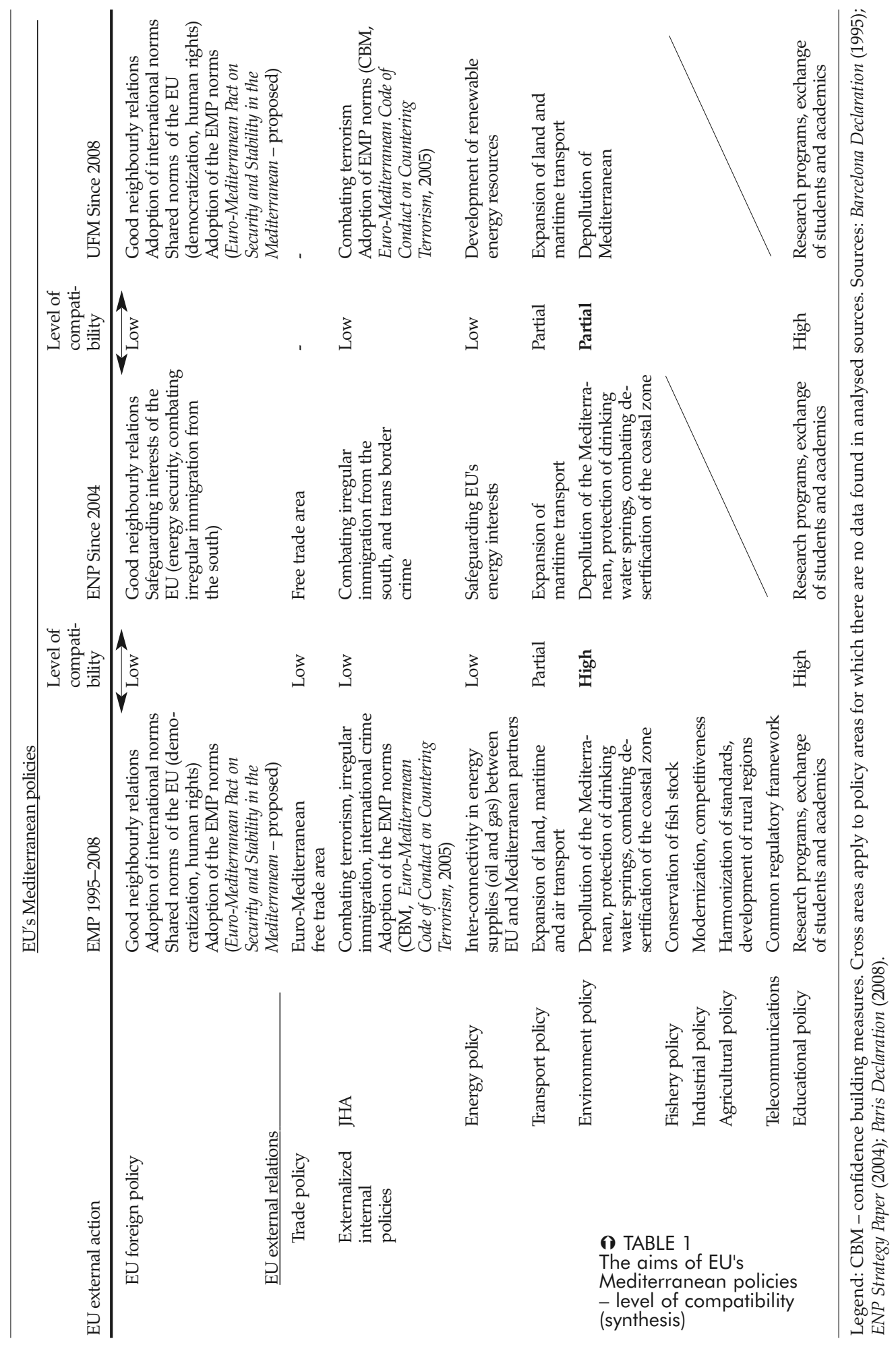


DRUŠ. ISTRAŽ. ZAGREB GOD. 28 (2019), BR. 3, STR. 483-502

BOJINOVIĆ FENKO, A., OSREČKI, A.:

THE (IN)COHERENCE...

(1) TABLE 2

Degree of coherence attained between EU's Mediterranean policies
(5) The aims of transport policy reveal a partial level of compatibility between the EMP, the ENP, and the UFM. The EMP tended to develop maritime and air interconnectedness with SMPs and land connectedness between SMPs only, whereas the ENP envisaged only maritime connectedness (which can be explained by maritime transport of energy resources to the EU space). Partial compatibility of aims exists between the ENP (maritime connectedness) and the UFM (maritime and land connectedness with and between SMPs).

(6) Transport policy demonstrates full compatibility of aims between the EMP and the ENP (depollution of the Mediterranean, protection of drinking water springs, and combating desertification of the coastal zone). However, we observe a partial level of aims' compatibility between the ENP and the UFM due to narrowing down the UFM's focus to the regional priority of depollution of the Mediterranean only.

(7) Education is the only externalized internal EU policy which has displayed continuingly high compatibility of aims (coherence) between all three EU Mediterranean policies by initiating and continuously preserving common research programs and exchange of students and academics.

Results reveal a different degree of coherence between the EMP, the ENP, and the UFM in foreign policy subfields, in trade policy and some externalized internal policies since 2004. Continuous incompatibility of policy aims has existed in externalized internal policies (JHA and energy policy) and in foreign policy between the EMP, the ENP and the UFM (see Table 2). We summarize that there is complete incoherence of EU foreign policy aims, while partial coherence exists within the EU functional policy subfields.

\begin{tabular}{|c|c|c|c|c|c|}
\hline & & & & $\begin{array}{l}\text { EMP - ENP } \\
2004-2008\end{array}$ & $\begin{array}{l}\text { ENP - UFM } \\
\text { since } 2008\end{array}$ \\
\hline \multirow{7}{*}{$\begin{array}{l}\text { EU } \\
\text { external } \\
\text { action }\end{array}$} & \multicolumn{3}{|c|}{ EU foreign policy } & Incoherent & Incoherent \\
\hline & \multirow{6}{*}{$\begin{array}{l}\text { EU } \\
\text { external } \\
\text { relations }\end{array}$} & \multicolumn{2}{|l|}{ Trade policy } & Incoherent & - \\
\hline & & Externalized & JHA & Incoherent & Incoherent \\
\hline & & internal & Energy policy & Incoherent & Incoherent \\
\hline & & policies & Transport policy & Partially coherent & Partially coherent \\
\hline & & & Environment policy & Coherent & Partially coherent \\
\hline & & & Educational policy & Coherent & Coherent \\
\hline
\end{tabular}

The EU's Mediterranean policies' incoherence was most prominent in the period from 2004 to 2008 between the ENP and the EMP concerning foreign policy, two externalized internal policies (JHA and energy policy) and trade policy. The situation has not substantially changed between the ENP and the UFM since 2008. Overall, the results strongly emphasize continuous incoherence between some specific externalized internal policies (JHA and energy policy) within all the EU's 
DRUŠ. ISTRAŽ. ZAGREB GOD. 28 (2019), BR. 3, STR. $483-502$

BOJINOVIĆ FENKO, A., OSREČKI, A.:

THE (IN)COHERENCE..
Mediterranean policies. Additionally, they point to only partial coherence of aims in increased number of externalized internal policies (transport and ecology policies) between the ENP and the UFM. These results fail to meet provisions stated in the founding documents of the ENP and the UFM, which emphasize continuation in the EU's Mediterranean policies.

\section{The implementation of the EU's Mediterranean Policies}

The analysis of the implementation of the EU's Mediterranean policies, focuses on the commitments on the side of SMPs in two clusters of subfields; political field (with emphasis on democratization and human rights as two analysed subfields) and JHA (with emphasis on irregular immigration and the fight against terrorism as two analysed subfields).

\section{Educational policy}

The above analysis has shown that the Educational policy is the only fully coherent externalized internal EU policy. Namely, the goals of this policy in the founding documents remain the same; cooperation among universities through mobility and exchange of students and support of Mediterranean partner states in modernizing their educational systems. We narrow our analysis down to a 5 -year period $(2011-2015)^{1}$ to present the degree of implementation of the 13 EU Mediterranean projects in the Educational policy as one of six sub-areas of the cultural-social basket (see Figure 1) by SMPs.

$\rightarrow$ FIGURE 1

Euro-Mediterranean regional projects from 2011-2015 in the cultural-social basket

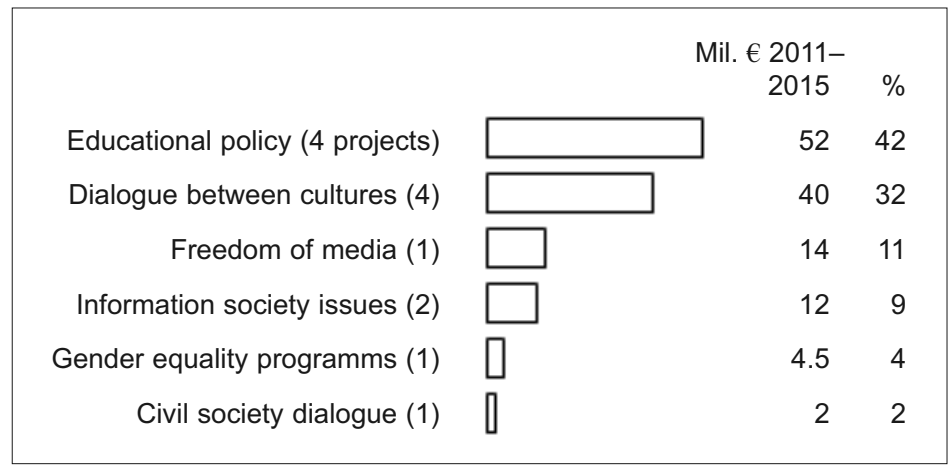

Source: Euro-Mediterranean Projects (see references)

Of the 13 Euro-Mediterranean projects, four have been implemented within the Educational policy (see Figure 2): Erasmus Mundus (European Region Action Scheme for the Mobility of University students), Tempus (Trans European Mobility Scheme for University Studies), Euro-Med Programme for Diplomatic Corps, and Euro-Med Training of Public Administration. These four projects have amounted to $€ 52$ million, which is the biggest budget compared to the other nine projects in five other 
DRUŠ. ISTRAŽ. ZAGREB GOD. 28 (2019), BR. 3, STR. 483-502

BOJINOVIĆ FENKO, A., OSREČKI, A.:

THE (IN)COHERENCE...

- FIGURE 2

Implementation of Euro-Mediterranean regional projects by the SMPs from 20112015 in the cultural-social basket sub-areas of the cultural-social basket. Three of these four projects have been implemented by ten of eleven SMPs. ${ }^{2}$

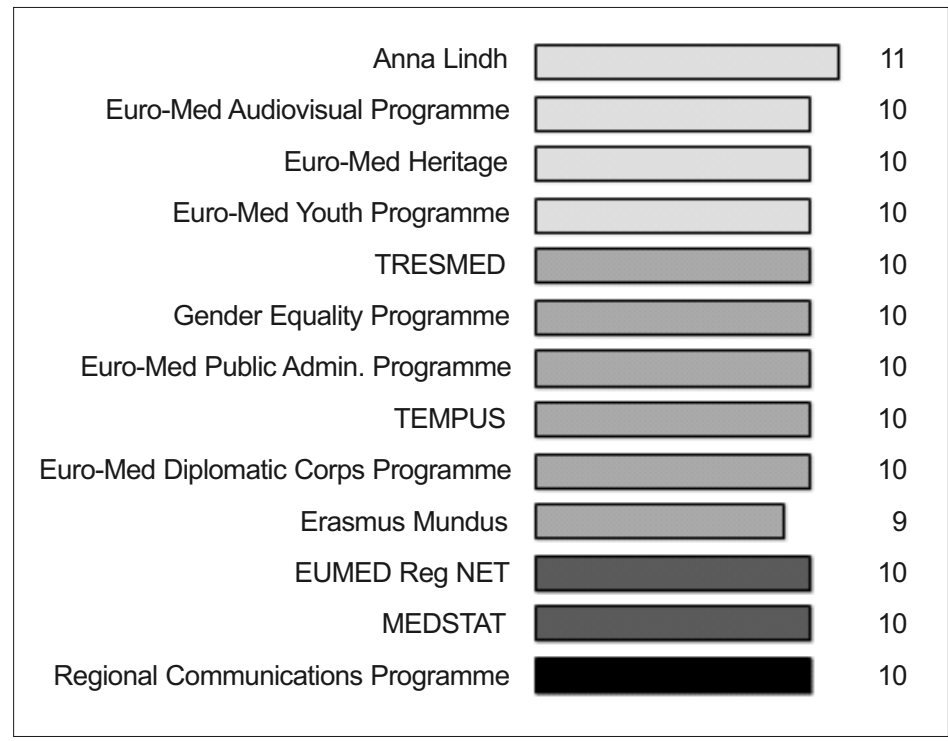

Source: See Figure 1.

\section{Political subfields}

There were 21 commitments adopted at EMCs in the political field, 11 of which were in the subfield of democratization (see Table 3). The rate of implemented (I), partially implemented ${ }^{3}$ (PI) or non-implemented (NI) commitments in this subfield by selected SMPs can be analysed either with attention to individual SMPs (vertically) or on the ratio of implementation (horizontally). Our analysis is based on the horizontal approach. Of 44 multilateral commitments (11 per each selected country) only 14 have been implemented, 12 partially implemented and 18 non-implemented. The sum of 30 PI + NI commitments compared to 14 I commitments reveals high disproportion between adopted and actually implemented commitments, and points to unsuccessful implementation of commitments on the side of SMPs in the democratization subfield.

The ratio of NI commitments from the same Table reveals that one particular NI commitment gains prominence by being left non-implemented in all four selected Mediterranean partner countries - active engagement of civil society groups in decision-making at all levels (emphasized in bold in Table 3).

There were 10 commitments adopted at EMCs in the subfield of human rights (see Table 4). Of 40 multilateral commitments (10 per each selected country) half of them or 21 have been I, 5 PI and 14 NI. The sum of 19 PI + NI commitments compared to 21 I commitments reveals the proportion of adopt- 
(1) TABLE 3

Implementation rate of commitments by selected SMPs in the subfield of democratization ed and actually implemented commitments, and points to a consistency in the implementation of adopted commitments on the side of SMPs in the subfield of human rights. Also, we note a small number of PI commitments evident in this subfield (only 5 compared to 12 in the democratization subfield), which leads to a conclusion that there is moderate tendency on the part of SMPs to change the content of adopted commitments in the human rights subfield.

\begin{tabular}{|c|c|c|c|c|c|c|}
\hline $\begin{array}{l}\text { Subfield: Democratization } \\
\text { Commitments }\end{array}$ & Source (EMCs) & $\begin{array}{l}\text { Bilateral ir } \\
\text { Morocco }\end{array}$ & $\begin{array}{l}\text { implem } \\
\text { Egypt }\end{array}$ & $\begin{array}{l}\text { entation } \\
\text { Jordan }\end{array}$ & $\begin{array}{l}\text { in } \mathrm{AP} \\
\text { Lebanon }\end{array}$ & $\begin{array}{l}\text { Ratio of } \\
\text { implementation }\end{array}$ \\
\hline $\begin{array}{l}\text { 1. Enhanced political dialogue } \\
\text { based on shared values of } \\
\text { democracy and the rule of law }\end{array}$ & Barcelona 1995 & NI & NI & NI & I & I 1, PI 0, NI 3 \\
\hline $\begin{array}{l}\text { 2. Democratization and em- } \\
\text { powerment of political parties }\end{array}$ & $\begin{array}{l}\text { Barcelona 1995; Valen- } \\
\text { cia 2002; Barcelona } 2005\end{array}$ & PI & PI & I & PI & I 1, PI 3, NI 0 \\
\hline $\begin{array}{l}\text { 3. Fair and transparent parliamen- } \\
\text { tary and local elections in accord- } \\
\text { ance with international treaties }\end{array}$ & Tampere 2006 & NI & NI & PI & $\mathrm{I}$ & I 1, PI 1, NI 2 \\
\hline $\begin{array}{l}\text { 4. Exchange of experience in } \\
\text { electoral process }\end{array}$ & $\begin{array}{l}\text { Barcelona 2005; Luxem- } \\
\text { bourg 2005; Marseilles } 2008\end{array}$ & PI & $P I$ & NI & NI & I 0, PI 2, NI 2 \\
\hline $\begin{array}{l}\text { 5. Increase in women's partici- } \\
\text { pation in the political decision- } \\
\text {-making process }\end{array}$ & Barcelona 2005 & PI & I & PI & I & I 2, PI 2, NI 0 \\
\hline 6. Independence of judiciary & Barcelona 2005 & NI & I & PI & NI & I 1, PI 1, NI 2 \\
\hline $\begin{array}{l}\text { 7. Judicial reform and improve- } \\
\text { ment of prison conditions }\end{array}$ & Dublin 2004 & I & $P I$ & $P I$ & $\mathrm{I}$ & I 2, PI 2, NI 0 \\
\hline $\begin{array}{l}\text { 8. Increased public participation } \\
\text { in the decision-making process }\end{array}$ & $\begin{array}{l}\text { Barcelona 2005; } \\
\text { Tampere } 2006\end{array}$ & NI & $P I$ & I & NI & I 1, PI 1, NI 2 \\
\hline $\begin{array}{l}\text { 9. Active engagement of civil } \\
\text { society groups in decision-mak- } \\
\text { ing at all levels }\end{array}$ & $\begin{array}{l}\text { Palermo 1998; Marseilles } \\
\text { 2000; Dublin 2004; Barce- } \\
\text { lona 2005; Tampere } 2006\end{array}$ & $\underline{\mathrm{NI}}$ & $\underline{\mathrm{NI}}$ & $\underline{\mathrm{NI}}$ & $\underline{\mathrm{NI}}$ & I 0, PI $0, \underline{\mathrm{NI}} 4$ \\
\hline $\begin{array}{l}\text { 10. Political dialogue between } \\
\text { the European Parliament and } \\
\text { parliaments of Mediterranean } \\
\text { partner states }\end{array}$ & $\begin{array}{l}\text { Barcelona 1995; Malta } \\
\text { 1997; Stuttgart 1999; Valen- } \\
\text { cia 2002; Dublin } 2004\end{array}$ & NI & I & I & I & I3, PI 0, NI 1 \\
\hline 11. Combating corruption & Barcelona 1995 & I & NI & NI & I & I $2, \mathrm{PI} 0, \mathrm{NI} 2$ \\
\hline Total & & $\begin{array}{l}\text { I } 2 \\
\text { PI } 3 \\
\text { NI } 6 \\
11\end{array}$ & $\begin{array}{l}\text { I } 3 \\
\text { PI } 4 \\
\text { NI } 4 \\
11\end{array}$ & $\begin{array}{l}\text { I } 3 \\
\text { PI } 4 \\
\text { NI } 4 \\
11\end{array}$ & $\begin{array}{l}\text { I } 6 \\
\text { PI } 1 \\
\text { NI } 4 \\
11\end{array}$ & $\begin{array}{l}\text { I } 14 \\
\text { PI } 12 \\
\text { NI } 18 \\
44\end{array}$ \\
\hline
\end{tabular}

Legend: I - implemented commitments; PI - partially implemented commitments; NI - non-implemented commitments; EMCs - Euro-Mediterranean conferences; AP - Action plans.

Sources: Euro-Mediterranean conferences (see references); Morocco Action Plan 2005; EU-Egypt Action Plan 2007; EU-Jordan Action Plan 2005; EU-Lebanon Action Plan 2007.

If we concentrate on the ratio of NI commitments from Table 4, then two NI commitments have been left non-implemented in all four selected SMPs - exchange of views on human rights practices, and identification of concrete areas of cooperation in human rights fora (emphasized in bold in Table 4). 
Subfield: Human rights Commitments

1. Implementation of international human rights standards

2. Promotion of dialogue with civil Bruxelles 2001; society in human right fora

3. Freedom of assembly, association, and promotion of independent media

4. Combating intolerance and discrimination based on religion or belief

5. Exchange of views on human rights practices

6. Identification of concrete areas of cooperation in human rights fora

7. Development of regulatory mechanism for implementation of human rights commitments

8. Gender equality

9. Promotion of fundamental social rights and decent working conditions

10. Combating corruption

Total

Crete 2003

Dublin 2004

Barcelona 1995

Barcelona 1995;
Valencia 2002

Barcelona 1995
Valencia 2002
Bilateral implementation in AP Ratio of

Morocco Egypt Jordan Lebanon implementation

$\begin{array}{lllll}\text { I } & \text { I } & \text { PI } & \text { I } & \text { I 3, PI 1, NI 0 } \\ \text { I } & \text { I } & \text { I } & \text { PI } & \text { I 3, PI 1, NI 0 } \\ \text { I } & \text { I } & \text { I } & \text { I } & \text { I 4, PI 0, NI 0 } \\ \text { NI } & \text { I } & \text { I } & \text { I } & \text { I 3, PI 0, NI 1 }\end{array}$

$\begin{array}{lllll}\text { NI } & \underline{\text { NI }} & \underline{\text { NI }} & \underline{\text { NI }} & \text { I 0, PI 0, } \\ \underline{\text { NI }} & \underline{\text { NI }} & \underline{\text { NI }} & \underline{\text { NI }} & \text { I 0, PI 0, } \\ & & & \end{array}$

Barcelona 1995; Marseilles 2000; Bruxelles 2001; Crete 2003; Naples 2003; Dublin 2004; Barcelona 2005

$$
\text { PI }
$$

$\begin{array}{lllll}\text { I } & \text { NI } & \text { I } & \text { I } & \text { I 3, PI 0, NI 1 } \\ & & & & \\ \text { I 5 } & \text { I 5 } & \text { I 5 } & \text { I 6 } & \text { I 21 } \\ \text { PI 1 } & \text { PI 1 } & \text { PI 1 } & \text { PI 2 } & \text { PI 5 } \\ \text { NI 4 } & \text { NI 4 } & \text { NI 4 } & \text { NI 2 } & \text { NI 14 } \\ \text { 10 } & \text { 10 } & \text { 10 } & \text { 10 } & 40\end{array}$

(1) TABLE 4 Implementation rate of commitments by selected SMPs in the subfield of human rights

- FIGURE 3 Implementation rate of obligations by selected SMPs in the Political field (in percentage)
Legend and sources: See Table 3.

To summarize, we present the rate of successful implementation of the EU's Mediterranean policies' goals in terms of commitments in the political field. $42 \%$ of commitments have been I, 20\% PI and a high 38\% NI (Figure 3). The sum of $58 \%$ PI and NI commitments demonstrates that the political field is implemented predominantly unsuccessfully.

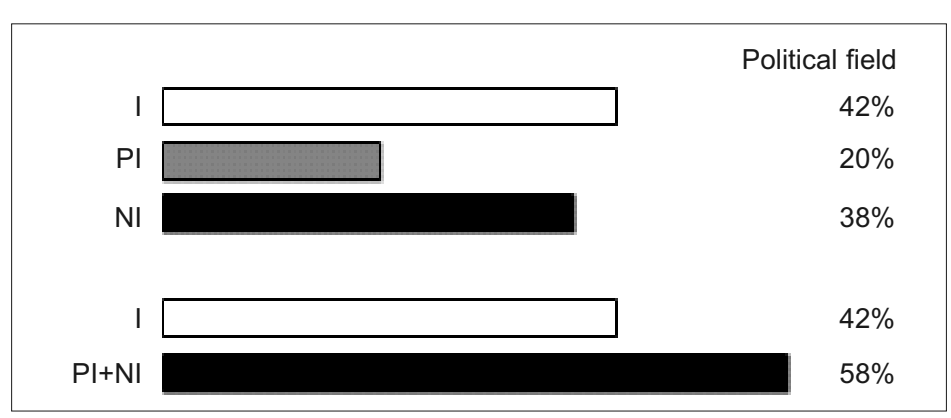


DRUŠ. ISTRAŽ ZAGREB

GOD. 28 (2019), BR. 3, STR. 483-502

BOJINOVIĆ FENKO, A., OSREČKI, A.:

THE (IN)COHERENCE..

(1) TABLE 5

Implementation rate of obligations by selected Mediterranean partner countries in the subfield of irregular immigration

\section{Justice, home affairs and migration (JHA) subfields}

There were 19 commitments adopted at EMCs in JHA subfields, 6 of which were in the subfield of irregular immigration (see Table 5). Out of 24 multilateral commitments (6 per each selected country) only 5 have been I, 1 PI and 18 or three quarters of them have been left NI. The sum of 19 PI + NI commitments compared to 5 I commitments is disproportionate to the adopted and actually implemented commitments, and points to unsuccessful implementation of the EU's Mediterranean policies in the JHA subfields. We particularly note 1 PI commitment in this subfield (compared to 12 in the democratization subfield and 5 in human rights), which points to a highly interesting conclusion: SMPs either fully implement multilaterally adopted commitments in the subfield of irregular immigration, or do not implement these commitments at all.

\begin{tabular}{|c|c|c|c|c|c|c|c|}
\hline \multirow{3}{*}{\multicolumn{2}{|c|}{$\begin{array}{l}\text { Subfield: Irregular immigration } \\
\text { Commitments } \\
\text { 1. Enhanced dialogue and exchange } \\
\text { of info on causes and negative } \\
\text { effects }\end{array}$}} & \multirow{3}{*}{$\begin{array}{l}\text { Source (EMCs) } \\
\text { Malta 1997; } \\
\text { Luxembourg } 2005\end{array}$} & \multicolumn{4}{|c|}{ Bilateral implementation in AP } & \multirow{2}{*}{$\begin{array}{l}\text { Ratio of } \\
\text { implementatior }\end{array}$} \\
\hline & & & Morocco & Egypt & Jordan & Lebanon & \\
\hline & & & I & I & I & I & I 4, PI 0, NI 0 \\
\hline 2. & $\begin{array}{l}\text { Negotiating readmission } \\
\text { agreements EU-Mediterranean } \\
\text { partners }\end{array}$ & $\begin{array}{l}\text { Barcelona 1995; Crete } \\
\text { 2003; Dublin 2004; } \\
\text { Barcelona 2005 }\end{array}$ & NI & I & NI & NI & I 1, PI 0, NI 3 \\
\hline 3. & $\begin{array}{l}\text { Negotiating series of readmission } \\
\text { agreements Mediterranean } \\
\text { partners-EU Member states }\end{array}$ & $\begin{array}{l}\text { Crete 2003; } \\
\text { Luxembourg } 2005\end{array}$ & $\underline{\mathrm{NI}}$ & $\underline{\mathrm{NI}}$ & $\underline{\mathrm{NI}}$ & $\underline{\mathrm{NI}}$ & I 0, PI 0, $\underline{\text { NI } 4}$ \\
\hline 4. & $\begin{array}{l}\text { Negotiating readmission } \\
\text { agreements Mediterranean } \\
\text { partners-third countries upon } \\
\text { request of the EU }\end{array}$ & $\begin{array}{l}\text { Crete 2003; } \\
\text { Luxembourg } 2005\end{array}$ & $\underline{\mathrm{NI}}$ & $\underline{\mathrm{NI}}$ & $\underline{\mathrm{NI}}$ & $\underline{\mathrm{NI}}$ & I 0, PI 0, $\underline{\mathrm{NI}} 4$ \\
\hline 5. & $\begin{array}{l}\text { Exchange of info about } \\
\text { transit migration }\end{array}$ & Barcelona 2005 & NI & NI & NI & PI & I 0, PI 1, NI 3 \\
\hline 6. & $\begin{array}{l}\text { Adoption of regional ap- } \\
\text { proach in combating } \\
\text { irregular immigration }\end{array}$ & $\begin{array}{l}\text { Barcelona 1995; Bru- } \\
\text { xelles 2001; Valencia } \\
\text { 2002; Naples } 2003\end{array}$ & $\underline{\mathrm{NI}}$ & $\underline{\mathrm{NI}}$ & $\underline{\mathrm{NI}}$ & $\underline{\mathrm{NI}}$ & I 0, PI 0, $\underline{\mathrm{NI}} 4$ \\
\hline & Total & & $\begin{array}{l}\text { I } 1 \\
\text { PI } 0 \\
\text { NI } 5 \\
6\end{array}$ & $\begin{array}{l}\text { I } 2 \\
\text { PI } 0 \\
\text { NI } 4 \\
6\end{array}$ & $\begin{array}{l}\text { I } 1 \\
\text { PI } 0 \\
\text { NI } 5 \\
6\end{array}$ & $\begin{array}{l}\text { I } 1 \\
\text { PI } 1 \\
\text { NI } 4 \\
6\end{array}$ & $\begin{array}{l}\text { I } 5 \\
\text { PI } 1 \\
\text { NI } 18 \\
24\end{array}$ \\
\hline
\end{tabular}

Legend and sources: See Table 3.

Our analysis of the ratio of NI commitments points that half of the adopted commitments on part of the SMPs are in this category and NI by all 4 states (emphasized in bold in Table 5): negotiation of a series of readmission agreements between SMPs and EU Member States; negotiation of readmission agreements between SMPs and third countries upon request of the EU; and adoption of regional approach in combating irregular immigration. 
DRUŠ. ISTRAŽ. ZAGREB GOD. 28 (2019), BR. 3, STR. 483-502

BOJINOVIĆ FENKO, A., OSREČKI, A.:

THE (IN)COHERENCE..

(1) TABLE 6

Implementation rate of commitments by

selected SMPs in fight against terrorism

subfield
There were 13 commitments (9 commitments and 4 subcommitments) adopted at EMCs in the subfield of fight against terrorism (see Table 6). When multiplied by four selected SMPs, we get to the number of 52 commitments. However, one commitment (implementation of an EMP legislative referring to the Euro-Mediterranean Code of Conduct in Countering Terrorism) could not be implemented in APs of Morocco and Jordan because their APs were adopted before the Code came into force (in 2005). This leads to 42 analysed commitments per four SMPs, 10 of which have been I, 5 PI and 27 NI. The sum of 32 PI + NI commitments compared to 10 I commitments reveals a significant disproportion between adopted and actually implemented commitments, and points to unsuccessful implementation of adopted commitments on the side of MPSs in the subfield of fight against terrorism.

\begin{tabular}{|c|c|c|c|c|c|c|c|}
\hline & $\begin{array}{l}\text { Subfield: Fight against terrorism } \\
\text { Commitments }\end{array}$ & Source (EMCs) & $\begin{array}{l}\text { Bilateral it } \\
\text { Morocco }\end{array}$ & $\begin{array}{l}\text { implem } \\
\text { Egypt }\end{array}$ & $\begin{array}{l}\text { entation } \\
\text { Jordan }\end{array}$ & $\begin{array}{l}\text { in } \mathrm{AP} \\
\text { Lebanon }\end{array}$ & $\begin{array}{l}\text { Ratio of } \\
\text { implementation }\end{array}$ \\
\hline 1. & $\begin{array}{l}\text { Extension of political dialogue } \\
\text { on sensitive aspects of terrorism }\end{array}$ & Marseilles 2000 & PI & PI & NI & $P I$ & I 0, PI 3, NI 1 \\
\hline 2. & $\begin{array}{l}\text { Ratification of international instru- } \\
\text { ments (conventions, regulations) }\end{array}$ & $\begin{array}{l}\text { Barcelona 1995; } \\
\text { Tampere } 2006\end{array}$ & I & I & $\mathrm{I}$ & I & I 4, PI 0, NI 0 \\
\hline 3. & Implementation of EU legislative & Dublin 2004 & $\underline{\mathrm{NI}}$ & NI & $\underline{\mathrm{NI}}$ & $\underline{\mathrm{NI}}$ & I 0, PI $0, \underline{\text { NI } 4}$ \\
\hline 4. & $\begin{array}{l}\text { Implementation of EMP legislative } \\
\text { (Euro-Mediterranean Code of Conduct } \\
\text { in Countering Terrorism) }\end{array}$ & $\begin{array}{l}\text { Barcelona 2005; } \\
\text { Paris 2008; } \\
\text { Marseilles } 2008\end{array}$ & & I & & I & I 2, PI 0, NI 0 \\
\hline & $\begin{array}{l}\text { 4.1 Exchange of info on } \\
\text { terrorists/terrorist networks }\end{array}$ & Barcelona 2005 & & $P I$ & & $P I$ & I 0, PI 2, NI 0 \\
\hline & $\begin{array}{l}\text { 4.2 Bilateral cooperation in } \\
\text { combating terrorism }\end{array}$ & Barcelona 2005 & & NI & & NI & I 0, PI 0, NI 2 \\
\hline & $\begin{array}{l}4.3 \text { Refusal of granting } \\
\text { asylum to terrorists }\end{array}$ & Barcelona 2005 & & NI & & NI & I 0, PI 0, NI 2 \\
\hline & $\begin{array}{l}\text { 4.4 Participation/observation in } \\
\text { counter-terrorism (CT) exercises }\end{array}$ & Barcelona 2005 & & NI & & NI & I 0, PI 0, NI 2 \\
\hline 5. & $\begin{array}{l}\text { Keeping records on ratified in- } \\
\text { ternational instruments of } \mathrm{CT}\end{array}$ & Stuttgart 1999 & $\underline{\text { NI }}$ & $\underline{\mathrm{NI}}$ & $\underline{\mathrm{NI}}$ & $\underline{\mathrm{NI}}$ & I 0, PI $0, \underline{\text { NI } 4}$ \\
\hline 6. & $\begin{array}{l}\text { Adoption of effective CT } \\
\text { policies }\end{array}$ & $\begin{array}{l}\text { Barcelona 1995; } \\
\text { Marseilles } 2000\end{array}$ & $\underline{\text { NI }}$ & $\underline{\mathrm{NI}}$ & $\underline{\mathrm{NI}}$ & $\underline{\mathrm{NI}}$ & I 0, PI $0, \underline{\text { NI } 4}$ \\
\hline 7. & $\begin{array}{l}\text { Identification of concrete } \\
\text { areas of joint activities in } \mathrm{CT}\end{array}$ & $\begin{array}{l}\text { Stuttgart 1999; Crete } \\
\text { 2003, Dublin 2004; } \\
\text { The Hague } 2004\end{array}$ & I & I & I & I & I 4, PI 0, NI 0 \\
\hline 8. & Joint CT exercises & Barcelona 2005 & $\underline{\text { NI }}$ & $\underline{\mathrm{NI}}$ & $\underline{\mathrm{NI}}$ & $\underline{\mathrm{NI}}$ & I 0, PI $0, \underline{\text { NI } 4}$ \\
\hline 9. & $\begin{array}{l}\text { Creation of Euro-Med network } \\
\text { of contact persons in CT efforts }\end{array}$ & Valencia 2002 & $\underline{\mathrm{NI}}$ & $\underline{\mathrm{NI}}$ & $\underline{\mathrm{NI}}$ & $\underline{\mathrm{NI}}$ & I 0, PI $0, \underline{\text { NI } 4}$ \\
\hline & Total & & $\begin{array}{l}\text { I } 2 \\
\text { PI } 1 \\
\text { NI } 5 \\
8\end{array}$ & $\begin{array}{l}\text { I } 3 \\
\text { PI } 2 \\
\text { NI } 8 \\
13\end{array}$ & $\begin{array}{l}\text { I } 2 \\
\text { PI } 0 \\
\text { NI } 6 \\
8\end{array}$ & $\begin{array}{l}\text { I } 3 \\
\text { PI } 2 \\
\text { NI } 8 \\
13\end{array}$ & $\begin{array}{l}\text { I } 10 \\
\text { PI } 5 \\
\text { NI } 27 \\
42\end{array}$ \\
\hline
\end{tabular}

Cross areas apply to commitments which Mediterranean partners could not implement due to their adoption after the ratification period of their AP. Legend and sources: See Table 3. 
DRUŠ. ISTRAŽ. ZAGREB GOD. 28 (2019), BR. 3, STR. $483-502$

BOJINOVIĆ FENKO, A., OSREČKI, A.:

THE (IN)COHERENCE... $\rightarrow$ FIGURE 4

Implementation rate of commitments by selected SMPs in JHA field (in percentage)
We also note 5 PI commitments in this subfield, the same as the number of PIs in the human rights subfield, but only half of the 12 PIs in the democratization subfield. This observation leads to the conclusion that SMPs exhibit an equal moderate tendency to change the content of adopted commitments in the subfields of human rights and fight against terrorism.

The analysis of the ratio of NI commitments from Table 6 points to no less than 5 of them having been left NI in all four selected SMPs (emphasized in bold in Table 6) - implementation of EU legislation; keeping records on ratified international instruments of counter-terrorism (CT); adoption of effective CT policies; joint CT exercises; and creation of a Euro-Med network of contact persons in CT efforts. We infer from this that there has been considerable reluctance on the part of SMPs for cooperation in this particular subfield.

To summarize findings in this subchapter, we present the rate of successful implementation of the EU's Mediterranean policies' goals in terms of commitments in the field of JHA. 23\% of commitments have been I, 9\% PI and a disproportionally high $68 \%$ of commitments NI. The sum of $77 \%$ of PI and NI commitments (PI + NI in Figure 4) confirms an overall less successful implementation in JHA subfields compared to the $58 \%$ of PI + NI in political subfields (democratization and human rights). This result is even additionally exacerbated in absolute terms, taking into consideration that the weight of at least PI is more than $100 \%$ lower in JHA compared to the political field JHA ( $9 \%$ vs $20 \%$ ).

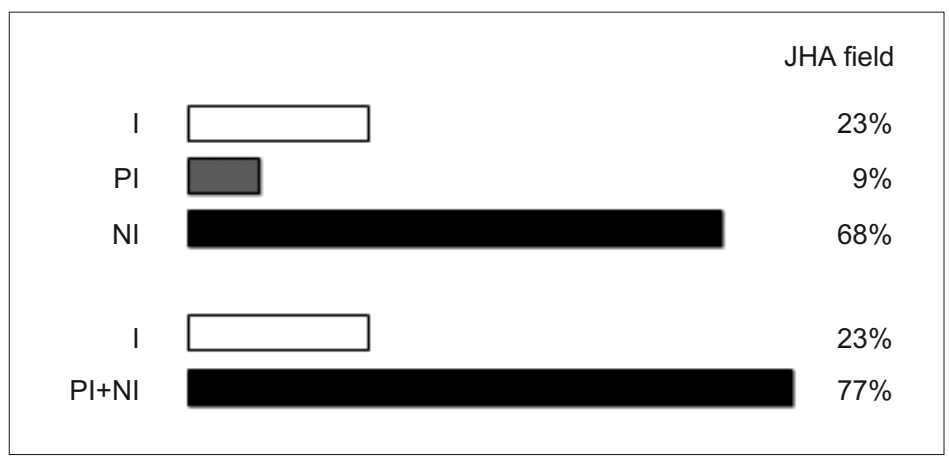

In this article, we tackle how coherence among three EU's Mediterranean policies affects the success of their implementation. With regards to the first hypothesis, we establish that the EU's Mediterranean policies reveal incoherence, i.e. incompatibility of their aims, in the EU foreign policy field and partial coherence in the subfields of the EU's external 
DRUŠ. ISTRAŽ. ZAGREB GOD. 28 (2019), BR. 3, STR. $483-502$

BOJINOVIĆ FENKO, A., OSREČKI, A.:

THE (IN)COHERENCE.. relations. As the latter refer to functional fields of cooperation, the first hypothesis can be confirmed, however, with some significant diversity within the functional subfields. For example, trade policy shows equally incoherent goals as foreign policy and so do the JHA and energy policy. Nevertheless, transport policy exposes partial coherence whereas the goals of environmental policy were compatible between the first two EU Mediterranean policies (the EMP and the ENP) but only partially compatible between the current two (the ENP and the UFM). The most coherent is the educational field of cooperation.

The empirical findings bring forward more arguments for strengthening on the second hypothesis as well, confirming that higher EU's Mediterranean policies' coherence correlates with implementation success. Educational functional cooperation as a highly coherent subfield is the only policy area that confirms successful engagement of SMPs in implementation. A largely failed implementation of commitments is exposed in the field of foreign policy as its subfields (democratization and respect for human rights) have proved to be highly politically sensitive for SMPs. However, it is the functional cooperation subfields within the JHA, namely the fight against irregular immigration and fight against terrorism, which proved an even less successful implementation. The first was only implemented by SMPs in $42 \%$ of projects and the latter in only $23 \%$. This result can be put into perspective mainly with the help of the fact that the fight against irregular immigration and against terrorism since the early 2000s does not pass for functional cooperation anymore. Due to renewed Arab-Israeli tension and 9/11 anti-terrorist measures, this subfield has become a highly sensitive issue in terms of international security and sovereignty.

Based on these findings, policy prescription inference suggests that in Mediterranean policies, the EU should focus on policy coherence first. During the policy implementation however, the EU should necessarily pay more attention to permanent verification of structural conditions that might change the nature of its policy goals from functional (politically unproblematic) to politically sensitive (as in cases of irregular migration and the fight against terrorism). In such instance, evidence of implementation success indicates it is wiser to directly reconceptualize a previously unproblematic functional subfield into a 'political cooperation', rather than introduce politically demanding conditions within functional cooperation. 
${ }^{1}$ This period is chosen in order to analyse projects on-going at the same time during all three EU Mediterranean policies.

${ }^{2}$ Morocco, Algeria, Tunisia, Libya, Egypt, Israel, Syria, Lebanon, Jordan, Palestinian Autonomy. Turkey is included in closer educational cooperation due to its EU accession process. The fourth project Erasmus Mundus has not been implemented by Libya due to its political instability since 2011 .

${ }^{3}$ We refer to PI when there is proof of partial commitment of SMPs. Partial commitment is a completely new commitment which does not entirely match to the content of the original multilateral one but still shows at least some degree of achieving the set aim compared to non-implementation.

\section{REFERENCES}

Adler, E., Bicchi, F., Crawford, B., \& Del Sarto, A. R. (Eds.) (2006). The convergence of civilisations. constructing a Mediterranean region. Toronto, Buffalo and London: University of Toronto Press.

Bicchi, F. (2012). The Union for the Mediterranean, or the challenging context of Euro-Mediterranean relations. In F. Bicchi \& R. Gillespie (Eds.), The Union for the Mediterranean (pp. 1-17). London and New York: Routledge.

Bojinović Fenko, A. (2009). An evaluation of the EU-Mediterranean region-building from the perspective of the regionalization process in the Mediterranean. In P. De Lombaerde \& M. Schulz (Eds.), The $E U$ and world regionalism: The makability of regions in the 21st century (pp. 187-203). Farnham and Bedlington: Ashgate.

Bretherton, C., \& Vogler, J. (2006). The European Union as a global actor. 2nd Edition. London: Routledge. https://doi.org/10.4324/9780203022672

Carbone, M. (2008). Mission impossible: The European Union and policy coherence for development. Journal of European Integration, 30(3), 323-342. https://doi.org/10.1080/07036330802144992

Cardwell, P. J. (2011). EuroMed, European neighbourhood policy and the Union for the Mediterranean: Overlapping policy frames in the EU's governance of the Mediterranean. Journal of Common Market Studies, 49(2), 219-241. https://doi.org/10.1111/j.1468-5965.2010.02119.x

Cebeci, M., \& Schumacher, T. (2017). The EU's constructions of the Mediterranean (2003-2017). MEDREST Working Paper No. 3. http://www. medreset.eu/wp-content/uploads/2017/04/medreset_wp_3.pdf

Consolidated version of the Treaty on European Union. Official Journal of the European Union. C83/30 March. http://eur-lex.europa.eu/legalcontent/EN/TXT/PDF/?uri=CELEX:12012E/TXT\&from =EN

Den Hertog, L., \& Strob, S. (2013). Coherence in EU external relations: Concepts and legal rooting of an ambiguous term. European Foreign Affairs Review, 19(3), 373-388.

Duke, S. (2011). Consistency, coherence and European Union external action: The path to Lisbon and beyond. In P. Koutrakos (Ed.), Eu- 
DRUŠ. ISTRAŽ. ZAGREB GOD. 28 (2019), BR. 3, STR. 483-502

BOJINOVIĆ FENKO, A., OSREČKI, A.:

THE (IN)COHERENCE.. ropean foreign policy: Legal and political perspectives (pp. 15-54). Cheltenham: Edward Elgar Publishing.

Conclusion from Euro-Mediterranean Conferences. http://trade.ec. europa.eu/doclib/cfm/doclib_section.cfm? sec $=152 \&$ link_types $=\&$ di $\mathrm{s}=20 \& \mathrm{sta}=1 \& \mathrm{en}=20$ \&page $=1 \&$ langId $=\mathrm{EN}$

Euro-Mediterranean projects from 2011-2015. http://www.programmemed.eu/en/the-projects/projectdatabase/results/view/listing. html?no_cache $=1 \&$ cHash $=1787848 f f d 63 f 96284 c 78 c 71 b 30 f 32 b 8 \#$

European Commission documents: European Neighbourhood Policy - Strategy Paper COM (2004) 373 final; EU-Morocco Action Plan 2005; EU-Jordan Action Plan 2005; EU-Lebanon Action Plan 2007; EU-Egypt Action Plan 2007. https://ec.europa.eu/transparency/regdoc/index.cfm?fuseaction $=$ search

Gauttier, P. (2004). Horizontal coherence and the external competences of the European Union. European Law Journal, 10(1), 23-41. https://doi.org/10.1111/j.1468-0386.2004.00201.x

Gebhard, C. (2011). Coherence. In C. Hill \& M. Smith (Eds.), International relations and the European Union. 2nd Edition (pp. 113-127). Oxford: Oxford University Press.

Gomez, R. (1998). The EU's Mediterranean policy: Common foreign policy by the back door? In J. Peterson \& H. Sjursen (Eds.), A common foreign policy for Europe (pp. 133-151). London: Routledge.

King, R. (1998). The Mediterranean, Europe's Rio Grande. In M. Anderson \& E. Bort (Eds.), The Frontiers of Europe (pp. 109-134). London and Washington: Pinter.

Krenzler, H., \& Schneider, H. (1997). The question of consistency. In E. Regelsberger, P. de Schoutheete, \& W. Wessels (Eds.), Foreign policy of the European Union: From EPC to CFSP and beyond (pp. 133-152). London: Lynne Rienners.

Nuttall, S. (2005). Coherence and consistency. In C. Hill \& M. Smith (Eds.), International relations and the European Union (pp. 91-112). Oxford: Oxford University Press.

Pace, M. (2006). The politics of regional identity. Meddling with the Mediterranean. London and New York: Routledge. https://doi.org/10.4324/ 9780203414521

Portela, C., \& Raube, K. (2012). The EU polity and foreign policy coherence. Journal of Contemporary European Research, 8(1), 3-20.

Smith, K. E. (2008). European Union foreign policy in a changing world. 2nd Edition. Cambridge and Malden: Polity Press.

Thomas, D. C. (2012). Still punching below its weight? Coherence and effectiveness in European Union foreign policy. Journal of Common Market Studies, 50(3), 457-474. https://doi.org/10.1111/j.1468-5965.2011. 02244.x

Tietje, C. (1997). The concept of coherence in the treaty on European Union and the common foreign and security policy. European Foreign Affairs Review, 2(2), 211-233. 
DRUŠ. ISTRAŽ. ZAGREB

GOD. 28 (2019), BR. 3, STR. 483-502

BOJINOVIĆ FENKO, A., OSREČKI, A.:

THE (IN)COHERENCE...
(Ne)koherentnost mediteranskih politika EU-a: analiza čimbenika koji utječu na uspješnost primjene

Ana BOJINOVIĆ FENKO

Fakultet društvenih znanosti, Ljubljana

Albina OSREČKI

Ministarstvo unutarnjih poslova Republike Hrvatske, Zagreb

Članak se bavi pitanjem jesu li dosadašnje tri mediteranske politike EU-a bile neuspješne zbog svoje nekoherentnosti. Definirana kao nekompatibilnost cilieva između EMP-a, ESP-a i UZM-a, nekoherentnost je analizirana kroz razna područja vanjskoga djelovanja EU-a, naime kroz funkcionalna područja eksternaliziranih unutarnjih politika (unutarnja pitanja i pravosuđe, energetika, transport, okoliš i obrazovanje) i vanjskih odnosa (trgovina) te kroz vanjsku politiku EU-a. Funkcionalne politike pokazale su se koherentnijima i s većim uspjehom u primjeni, što je predstavljeno na primjeru obrazovanja. Nasuprot njima, politička područja (demokratizacija, poštivanje ljudskih prava) razotkrivaju nekoherentnost te 50 postotnu neuspješnost u primjeni. Međutim, unutarnja pitanja i pravosuđe (posebno suzbijanje migracija i terorizma), u kojima je sadašnja funkcionalna suradnja postala visoko politizirana, rezultiraju najvišim stupnjem neprimjene, što postaje sve relevantnije za proces odlučivanja na razini vanjskoga djelovanja EU-a.

Ključne riječi: mediteranske politike EU-a, nekoherentnost, neprimjena, vanjsko djelovanje EU-a

\section{(c) $($ i) (8)}

Međunarodna licenca / International License:

Imenovanje-Nekomercijalno/ Attribution-NonCommercial 